\title{
Are curriculum changes the ideal method for increasing undergraduate exposure to tomorrow's specialties?
}

This article was published in the following Dove Press journal:

Advances in Medical Education and Practice

10 March 2015

Number of times this article has been viewed

\author{
Savan Shah \\ Imperial College, London, UK
}

Correspondence: Savan Shah Imperial College, Imperial College Road, South Kensington, London SW7 2AZ, UK Email savan.shah09@imperial.ac.uk

\section{Dear editor}

Smaller specialties such as dermatology, psychiatry, and radiology have often received less teaching time within the undergraduate medical curriculum. ${ }^{1}$ Some critics argue that this may be responsible for the low intake rates within postgraduate training for these specialties. The Royal College of Psychiatrists reported that only $83 \%$ of core training post vacancies were filled after two rounds of recruitment in 2012. ${ }^{2}$ Furthermore, the National Health Service identified a shortfall of 220 interventional radiologists in the UK. ${ }^{3}$ Similar workforce problems have been encountered in the USA. ${ }^{4}$ It has been suggested that increasing exposure to these specialties in medical school may allow students to gain a better insight into the specialty and consider it as a viable future career choice. ${ }^{1}$ Although incorporating more dedicated teaching time for small specialties within the curriculum may help to meet future workforce demands, there are strong arguments against implementing it. First of all, teaching time would have to be taken away from the core specialties to accommodate more teaching for smaller specialties. However, knowledge and skills within the core specialties is more important for building a strong foundation for any future career choice. There is no robust evidence to suggest that students would still receive adequate training in core specialties if smaller specialties are given more time. Second, the overall workforce requirements are much greater for the core specialties and the majority of graduates are more likely to enter the core rather than the smaller specialties.

Perhaps a different approach is required. In order to tackle the current shortfall in psychiatrists, the Royal College of Psychiatrists has adopted a particularly strong strategy. ${ }^{2}$ This includes setting up/supporting medical school societies, regular career fairs, annual summer schools, intercalated Bachelor of Science programs, and student elective modules to engage and educate medical students. In addition, financial incentives (including bursaries/grants for conferences, electives, and research, essay prizes, and fellowships) have been used to promote and reward student activity across the variety of psychiatric subspecialties. Although these methods may not have the direct impact of dedicated teaching, they provide ample opportunity for students to explore the smaller specialties without detracting unnecessarily from the core curriculum.

\section{Disclosure}

The author reports no conflicts of interest in this work. 


\section{References}

1. Kumar K, Xie F. Expanding horizons: increasing undergraduate exposure to tomorrow's specialties. Med Teach. 2014;36(12):1088-1089.

2. Royal College of Psychiatrists. Recruitment Strategy 2011-2016: RCPSYCH; 2012. Available from: http://www.rcpsych.ac.uk/pdf/Recruitment\%20Strategy\%20-\%2010092013.pdf. Accessed January 20, 2015.
3. NHS Improvement Diagnostics. Towards Best Practice in Interventional Radiology: NHS; 2012. Available from: http://www.nhsiq.nhs. uk/resource-search/publications/nhs-imp-best-practiceir.aspx. Accessed December 12, 2014.

4. Morello FA Jr, Murphy WA Jr. Ensuring the radiologist workforce: opportunities during education. J Am Coll Radiol. 2004;1(11):848-853.

\section{Publish your work in this journal}

Advances in Medical Education and Practice is an international, peerreviewed, open access journal that aims to present and publish research on Medical Education covering medical, dental, nursing and allied health care professional education. The journal covers undergraduate education, postgraduate training and continuing medical education including emerging trends and innovative models linking education, research, and health care services. The manuscript management system is completely online and includes a very quick and fair peer-review system. Visit http://www.dovepress.com/testimonials.php to read real quotes from published authors.

Submit your manuscript here: http://www.dovepress.com/advances-in-medical-education-and-practice-journal 